\title{
Intrapersonal factors and role of community leaders in the event of diarrhea in sub- district Paringin
}

\author{
Aan Nurhadi*, Bahrul Ilmi, Lenie Marlinae \\ Faculty of Medicine, Lambung Mangkurat University, South Kalimantan, Indonesia
}

\section{A R T I CLE INF O}

\section{Article history:}

Received 9 May 2016

Received in revised form

15 June 2016

Accepted 19 June 2016

\section{Keywords:}

Intrapersonal factors

Community leaders

Diarrhea

\begin{abstract}
A B S T R A C T
Incidence of diarrhea in Paringin has not decreased significantly. Diarrhea can be caused by environmental sanitation, intrapersonal factors and social factors. This study aims to assessing the role of community leaders and intrapersonal factors with the incidence of diarrhea in the household connection beneficiaries Adaro's CSR program. Research with mixed methods models of sequential explanatory design. Qualitative samples are seven leaders of community and quantitative are 164 households. Result is community leader's act as educators on the type of sanitary facilities, sanitary facilities ownership, CTPS behavior. As an activator on the type of sanitation facilities and the behavior of drinking water usage. As a motivator on the type of sanitation facilities, behavioral CTPS, ownership of the means of waste disposal. As a facilitator only in possession of a means of waste disposal. As catalysts, planners and supervisors in the ownership of the means of sanitation, trash disposal facilities ownership and waste. As a role model only in possession of disposal waste facilities. As a planner and supervisor is an additional role. There was no relationship between intrapersonal factors either partially or simultaneously with the incidence of diarrhea. There are many factors which can affect in the incident. However, age, education and income form intrapersonal factor. Conclusion is the role of community leaders as an extension, propulsion, motivator, facilitator, catalyst, exemplary, planners and supervisors.
\end{abstract}

(C) 2016 The Authors. Published by IASE. This is an open access article under the CC BY-NC-ND license (http://creativecommons.org/licenses/by-nc-nd/4.0/).

\section{Introduction}

Diarrhea is a disease that can reduce productivity and cause death. In Indonesia, the number of diarrhea recorded $423 / 1000$ population in all age groups and 16 provinces experienced Extraordinary Events (KLB) with Case Fatality Rate (CFR) of 2.52. Data UNICEF Indonesia in 2012 said diarrhea is the main cause of $88 \%$ of deaths in children are caused by the behavior of poor sanitation and drinking water unsafe. Sukana et al. (2005) stated that the incidence of diarrhea, caused by low education and distance of the house with a pile of trash. Another risk factor is the level of education, level of knowledge, hygiene behavior, habits of mothers throwing feces of infants and habits of mothers using cleanwater (Adisasmito, 2007; Eralita, 2011).

\footnotetext{
* Corresponding Author.

Email Address: aan.nurhadi06@gmail.com (A. Nurhadi) http://dx.doi.org/10.21833/ijaas.2016.07.002

2313-626X/@ 2016 The Authors. Published by IASE.

This is an open access article under the CC BY-NC-ND license

(http://creativecommons.org/licenses/by-nc-nd/4.0/)
}

Villagers of Paringin Sub-district have been assigned the clean water programs in the form of household connections (SR) from the CSR program PT Adaro Indonesia. From 2010 to 2014, the company cooperated with Balangan Local Water Company has installed SR in 10 villages in the Subdistrict Paringin with as many as 923 household beneficiaries. The use of river water is still done because of the low-level of knowledge. On the other hand, water quality cannot be guaranteed because the government has not been able to control river water pollution from sewage potential (Putri, 2011).

Incidence of diarrhea has not a significant reduction. Based on data from Paringin PHC, the number of diarrhea in a row from 2011 to 2014 was 323 cases, 330 cases, 328 cases and 353 cases. In fact, the water produced by the Balangan Local Water Company (PDAM) appropriate health parameters

Another risk factor for the cause of diarrhea is the role of community leaders. Indeed, South Kalimantan people's behavior to trust the words and deeds of people who featured, although there are insufficiently understanding related to the value or information of the community leaders who then 
brought sociological impact or effect on the lives of everyday people.

Based on the description above, the question in this research is what causes the high incidence of diarrhea in the community households' connections program beneficiaries (SR) of CSR PT Adaro Indonesia.

\section{Material and methods}

The design of this study was a mixed method with a sequential exploratory design. This method is in the early stages using qualitative methods and the next phase using quantitative methods with qualitative priorities first and then reinforced with quantitative data combination of both methods is connecting (Creswell, 2014; Sugiono, 2012). Method of collecting data obtained through the study of documentation, interviews, and direct observation.

The study population was 923 beneficiary households. Qualitative samples as many as seven community leaders and quantitative sample as many as 164 households to test the hypothesis of two proportions and cluster sampling.

\section{Results and discussion}

\subsection{Qualitative research results}

The role of community leaders in this study focused on assessing the role of community leaders towards the type of sanitation facilities, ownership of the means of sanitation, the behavior of the use of drinking water, hand washing with soap (CTPS), the ownership of means of trash disposal and ownership of the means of waste disposal on the household connection beneficiaries program of CSR PT Adaro Indonesia. Based on the results of qualitative research, the role of community leaders is very diverse ranging from educator, activator, motivator, facilitator, catalyst to role model.

The role of community leaders is one risk factor that is very important and contributes to the incidence of diarrhea. Although people have been willing and able to adopt healthy behaviors, but did not do for their specific impulse. Indeed, South Kalimantan people's behavior to trust the words and deeds of people who featured, although there are steady understanding related to the value or information of the community leaders who then brought sociological impact or effect on the lives of everyday people. The figure is then through social networks played a major role in people's behavior. Social network in South Kalimantan can be a high genetic relationship between individuals, family members, friends or neighbors who always socialize in household activities, religious groups, sports or other associations that exist in the community.

Based on the results of qualitative research related to the role of community leaders, role as an educator, activator and motivator very attached to the type of sanitation facilities, ownership of the means of sanitation, drinking water usage behavior, behavior CTPS and ownership of the means of waste disposal. The community leaders are village heads, religious leaders, youth leaders and village midwives. This is consistent with the theory of achievement motivation of David Mc. Clelland (1917) in which there are motivations need for power, the need for which is reflected in a person who has influence over others, sensitive to the structure of influence between individuals and try to dominate others by trying to regulate the behavior of the person and to impress him and always keep reputation and status. So from the role of community leaders as an educator, activator and motivator of community leaders were able to change the mindset and motivate the community to improve the type of sanitation, ownership of the means of sanitation, drinking water usage behavior, behavior CTPS and ownership of the means of waste disposal.

In addition, the role of community leaders as facilitators and catalysts are also attached to the ownership of the means of sanitation, ownership of trash disposal facilities and ownership of the means of waste disposal. The public figure is the heroine and chief of the village and the village midwife. This happens due to the ability of community leaders provide easiness to identify potential, acts as a liaison and resource to approach competent partners to find solutions to problems that occur in the community. The way in which the approach to partners or agencies both inside and in the environment. The village head and village midwives have realized that she became a leader for the people who can help solve the problems in the village. It also supports the village head and village midwives serving as role models in the ownership of the means of waste disposal.

This is in accordance with The Regulation of Health Minister Number 65 Year 2013 about guidelines for the implementation of community empowerment health, stating that $70 \%$ of development resources from the village where the village has a community leadership, community organization and community decision making process that is on public figures. This is also consistent with attribution of leadership theory, in which there are theories of charismatic leadership, the leader who is judged to have extraordinary ability in the middle of the community. The fact is one of the community leaders who were considered charismatic by the villagers so they can be role models.

Based on in-depth interviews on community leader, there are other roles that are attached to public figures, namely as a planner for the assistance to be provided, assistance from government and private agencies. Community leaders active in preparing proposals that will be in the fund by moving the village officials. Not only that, based on field observations, community leaders are also active in supervising the work of the aid, both aid directly done by communities or assistance undertaken by donors, community leaders actively communicate 
relevant information to the development of fieldwork and obstacles that occur. It happened because community leaders have been aware of the geographical location of the village is located in the area of the ring 1 , so that there is clarity of CSR Adaro aid resources. In accordance with the regulation of social and environmental responsibility as stipulated in Law No. 40/2007 and Government Regulation No.47/2012 on the obligation to carry out community development programs in the area of operations of the company and are transparents.

Based on the results of qualitative research on the role of community leaders on the type of sanitation facilities, ownership of the means of sanitation, drinking water usage behavior, CTPS behavior, ownership means of trash disposal and ownership means of waste disposal facilities.
Based on the results of the qualitative research, the role of community leaders most dominant existing on religious figure, which is then followed by the village head and village midwives. Three community leaders play an active role in society, both act as educator, activator, motivator, facilitator, a catalyst to role model in the middle of the community.

\subsection{Quantitative research results}

\subsubsection{The relationship between the independent variables and the dependent variable}

The result of statistical analysis for each relationship independent variable on the dependent variable is shown in Table 1.

Table 1: Statistical test results of independent variables with the dependent variable

\begin{tabular}{|c|c|c|c|}
\hline No. & Variables & P Value & Information \\
1 & Age & 0.610 & Meaningless \\
\hline 2 & Level of education & 1.000 & Meaningless \\
\hline 3 & Job status & 0.610 & Meaningless \\
4 & Income level & 0.281 & Meaningless \\
\hline 5 & Number of family members & 0.777 & Meaningless \\
\hline 6 & Type of sanitation facilities & 0.617 & Meaningless \\
7 & Drinking water usage behavior & 1.000 & Meaningless \\
\hline 8 & Ownership of sanitation facilities & 0.544 & Meaningless \\
9 & CTPS behavior & 0.521 & Meaningless \\
10 & Ownership means of trash disposal & 1.000 & Meaningless \\
11 & Ownership means of waste disposal & 0.679 & Meaningless \\
\hline
\end{tabular}

Based on the Table1 it can be known if the pvalue of all variables above 0.05 . That means that the independent variables had not a significant relationship with the incidence of diarrhea (dependent variable).

\subsubsection{Intrapersonal factors relationship to the events of diarrhea}

Based on the results of statistical analysis smartPLS, only 3 variables from 11 variables were significantly shape intrapersonal factors such as age (loading $=0.455, \mathrm{p}$-value $=0.02$ ), educational level (loading $=0.667, \mathrm{p}$-value $=0.03$ ) and income level (loading $=0.572, \mathrm{p}$-value $=0.05$ ) . Based on the test also known relationship between intrapersonal factors with the incidence of diarrhea. Value of effect size is the relationship between these two variables, in this case is $r^{2}=-0.002$ which means it is intrapersonal factors as predictor latent variable give negative effect to incidence of diarrhea. This is also supported by the value of $\mathrm{R}^{2}=0.000$, which means it is the influence of intrapersonal $0 \%$ of the incidence of diarrhea. As well as evidenced by the $p$ value $=0.490$, which means no significant correlation between intrapersonal factors with the incidence of diarrhea.

The level of education and income levels, including in the socio-economic environment. Socioeconomic environment is a factor that affects almost all aspects of life, well-being, the health status of the community or community development is often used as an indicator of social economy that can determine the level of welfare or health status and community development (Soetjiningsih, 2004). It is also reinforced by the results of research Amalia (2009) where the level of education and income levels significantly associated with clean and healthy living behaviors (PHBS).

\section{Conclusion}

a. The role of community leaders as educators there on the type of ownership of the means of sanitation facilities, potable water use behavior and the behavior of hands washing with soap (CTPS), as an activator there on the type of sanitation facilities and the behavior of the use of drinking water, as a motivator there on the type of sanitation, hand washing with soap (CTPS) and the ownership of the means of waste disposal, as facilitators is in possession of a means of trash disposal, as a catalyst there on the type of ownership of the means of sanitation facilities, ownership of the means of trash disposal and ownership of the means of waste disposal, as role models there on the type of ownership of the means of waste disposal, as a planner in the ownership of the means of sanitation, ownership of the means of trash disposal and ownership of the means of waste disposal, as supervisor on the ownership of the means of sanitation, ownership 
of the means of trash disposal and ownership of the means of waste disposal.

b. There is no significant relationship between age, education level, type of work, income level, family size, type of sanitation, ownership of the means of sanitation, the behavior of the use of drinking water, hand washing with soap (CTPS), ownership of the means trash disposal and ownership of the means waste disposal with the incidence of diarrhea in the communities household connection program beneficiary of CSR PT Adaro Indonesia.

c. There is no significant relationship between intrapersonal factors simultaneously with the occurrence of diarrhea in the household connection beneficiaries CSR program PT Adaro Indonesia.

d. There are three variables that make up the intrapersonal factors, such as age, education level and income level.

\section{Acknowledgement}

Thank you we present to Rector and Dean of the Faculty of Medicine Lambung Mangkurat University. In addition, thank you very much, we say to the Chairman of the Master of Public Health Sciences Study Program and all staff. CSR PT. Adaro Indonesia, Paringin Sub-District and Balangan District, PHC Paringin, and all respondent.

\section{References}

Adisasmito W (2007). Diarrhea risk factors in infants and toddlers in indonesia: systematic review of public health academic research. Makara Journal of Health, 11(1): 1-10.

Amalia I (2009). Relationship between education, income with clean and healthy behavior (PHBS) in merchant dishes specialties in kliwon market and jebres surakarta. Public Health Study Program, Faculty of Health, Muhammadiyah Surakarta University, Indonesia.

Creswell JW (2014). A concise introduction to mixed methods research. Sage Publications, University Of Nebraska, Lincold, USA.

Eralita (2011). Relations environmental sanitation, knowledge and mothers behavior against acute diarrhea in toddlers in sub pahandut palangkaraya. M.Sc Thesis in Medicine, University of Gajah Mada University, Yokyakarta.

Putri D (2011). Government policy in river water pollution control (A case study watershed siak section downstream). Journal of Political Science and Public Administration, 1(1): 68-79.

Soetjiningsih (2004). Growth. Book Medical Publishers EGC, Jakarta, Indonesia. 